\title{
PELATIHAN PENERAPAN SISTEM “APARTEMENT" BAGI BUDIDAYA CACING SUTRA PADA KELOMPOK PEMBUDIDAYA IKAN CUPANG DI DESA KAMPUNG BARU, KECAMATAN LANGSA LAMA, KOTA LANGSA
}

\author{
Suri Purnama Febri'1), Teuku Fadlon Haser ${ }^{11}$, Andri Yusman Persada ${ }^{2)}$, Kartika Aprilia Putri²), \\ Herlina Putri Endah Sari²)
}

\author{
1)Program Studi Budidaya Perairan, Fakultas Pertanian, Universitas Samudra, Aceh, Indonesia \\ 2)Program Studi Biologi, Fakultas Teknik, Universitas Samudra, Aceh, Indonesia \\ Corresponding author : Teuku Fadlon Haser \\ E-mail : teukufadlon@unsam.ac.id
}

Diterima 02 November 2021, Disetujui 08 November 2021

\begin{abstract}
ABSTRAK
Cacing sutra merupakan pakan hidup yang disukai ikan khususnya larva ikan. Hal ini karena ukurannya yang kecil sehingga mudah dimakan. Kesesuaian pakan hidup yang diberikan akan semakin membuat besar larva ikan hidup dan tumbuh. Tujuan dari kegiatan pengabdian kepada masyarakat ini yaitu membantu mitra untuk meningkatkan hasil produksi ikan cupang dengan pemberian cacing sutra yang dibudidayakan dengan sistem apartement. Metode yang digunakan melalui beberapa tahap, yaitu sosialisasi, pendampingan, monitoring dan evaluasi. Sosialisasi dilakukan untuk memberikan informasi yang lebih jelas tentang maksud dan tujuan tim mengadakan pelatihan penerapan sistem Apartement. Pendampingan dilakukan berupa pembuatan sistem apartemen dan pembuatan pakan cacing sutra dengan menggunakan ampas tahu yang difermentasikan menggunakan larutan EM 4 dan molase selama 3 hari, kemudian pakan siap digunakan. Hasil monitoring dan evaluasi mitra mampu serta terampil membuat wadah sistem apartemen serta pakan cacing sutra dari ampas tahu. Selanjutnya mitra juga sudah sangat faham bagaimana pola kerja dalam melakukan budidaya cacing serta dengan menggunakan sistem apartemen.
\end{abstract}

Kata kunci: cacing sutra; sistem apartement; ikan cupang; desa kampung baru.

\begin{abstract}
Tubifex sp. are live food that is preferred by fish, especially fish larvae. This is because of its small size so it is easy to eat. The suitability of the live feed given will make the larger fish larvae live and grow. The purpose of this community service activity is to help partners to increase the production of betta fish by giving silk worms that are cultivated with the apartment system. The method used goes through several stages, namely socialization, mentoring, monitoring and evaluation. The socialization was carried out to provide clearer information about the goals and objectives of the team holding training on the application of the Apartment system. Assistance is provided in the form of building an apartment system and making feed for Tubifex sp. by using tofu dregs which was fermented using EM 4 solution and molasses for 3 days, then the feed was ready for use. The results of monitoring and evaluation of partners are capable and skilled in making apartment system containers and tubifex sp. feed. from tofu dregs. Furthermore, partners also understand very well how the work pattern in cultivating Tubifex sp. using the apartment system.
\end{abstract}

Keywords: tubifex sp. apartment system; Betta splend; kampung baru village.

\section{PENDAHULUAN}

Indonesia memiliki keanekaragaman hayati yang tinggi, khususnya biota perairan. Salah satu biota perairan yang berpotensi untuk dikembang adalah biota air tawar. Ikan air tawar dapat dimanfaatkan sebagai bahan pangan dan ikan hias. Salah satu ikan hias yang berpotensi untuk dibudidaya adalah ikan cupang yang memiliki nilai ekonomi yang tinggi.

Ikan cupang (Betta splendens) merupakan ikan hias yang sedang diminati oleh masyarakat Kota Langsa. Ikan ini merupakan salah satu ikan hias yang sangat diminati karena warna sirip dan sisiknya yang berwarna menarik. Hal ini tergantung dengan pigmen yang berada di kromatophor. Menurut Prasadi (2019), ikan cupang (Betta splendens) merupakan ikan yang mudah untuk dibudidaya dan mengalami pengembangbiakan. Budidaya ikan cupang tidak memerlukan teknik yang rumit dan aerasi karena ikan cupang mampu hidup pada kondisi air yang tenang. Pada 
budidaya ikan cupang, pemberian jenis pakan yang tepat dapat mempengaruhi pertumbuhan dan perkembangan ikan cupang.

Kelompok Pembudidaya Ikan yang berada di Kampung Baru Gang Bakti merupakan salah satu kelompok budidaya ikan cupang yang ada di Kota Langsa. Kelompok ini berada di Langsa Lama yang terletak tidak jauh dari pusat kota. Kelompok ini diketuai oleh bapak Rustam. Berdasarkan survei awal dan wawancara yang telah dilakukan, harga ikan cupang berkisar Rp. $5.000-1.000 .000$ per ekor tergantung besar, warna dan motif yang ada pada ikan cupang. Pemeliharaan ikan cupang tidak sulit karena dapat dilakukan pada area yang sempit dan tanpa perlakuan khusus pada air.

Pada pembudidayaan ikan cupang, dibutuhkan pakan berupa pelet dan pakan hidup. Pakan pelet memiliki harga bervariasi mulai Rp. 10.000 - 50.000 per botol atau kemasan. Selain itu, diperlukan pakan hidup untuk membantu pertumbuhan dan perkembangan ikan cupang seperti jentik. Kehadiran jentik secara alami semakin sedikit karena semakin meningkatnya jumlah pembudidaya ikan yang menggunakannya sebagai pakan hidup. Harga pelet yang tinggi dan kesulitan mencari pakan hidup merupakan kendala yang dirasakan oleh Kelopok Pembudidaya Ikan Kampung Baru. Menurut Diani et al., (2005), pemberikan pakan hidup yang berkesinambungan pada usaha pembenihan ikan cupang mendukung keberhasilan produksi benih. Salah satu pakan hidup yang dapat dimanfaatkan untuk budidaya ikan cupang adalah cacing sutra (Tubifex sp.) (Hamron et al, 2018).

Cacing sutra merupakan pakan hidup yang disukai ikan khususnya larva ikan. Hal ini karena ukurannya yang kecil sehingga mudah dimakan oleh larva ikan. Kesesuaian pakan hidup yang diberikan akan semakin besar larva ikan hidup dan tumbuh. Cacing sutra hidup pada perairan yang berlumpur kaya akan bahan organik. Effendi (2017), mengatakan bahwa cacing sutra hidup pada substrat lumpur dengan kedalaman $0-4 \mathrm{~cm}$. Substrat yang kaya akan nutrien membantu pertumbuhan dan nutrisi yang terkandung dalam cacing sutra. Penambahan kandungan nitrogen dan fosfor pada media budidaya mampu meningkatkan pertumbuhan cacing sutra (Febrianti, 2020). Salah satu teknik budidaya cacing sutra dengan teknik "apartement". Pada teknik ini wadah untuk budidaya cacaing sutra di desain sedemikian rupa menjadi wadah yang bertingkat seperti apartement. Wadah teratas dilengkapi dengan air secara resirkulasi tertutup. Media yang digunakan adalah fermentasi ampas tahu dan bahan organik dengan perbandingan $4: 1$.

Tahapan budidaya ikan hias yang sangat krusial berada pada fase larva hingga benih, sehingga menjadi permasalahan tersendiri yang harus diselesaikan. Permasalahan yang dihadapi pembudidaya ikan hias saat ini adalah rendahnya teknologi dan pengetahuan yang dimiliki Kelompok Pembudidaya Ikan Kampung Baru tentang budidaya pakan hidup. Untuk itu diperlukan adanya informasi dan pelatihan yang akurat terkait teknologi budidaya cacing sutra sebagai pakan hidup yang dapat dimanfaatkan oleh pembudidaya ikan hias terutama budidaya ikan cupang.

Permasalahan utama yang dihadapi mitra selama ini adalah tingginya biaya pakan pelet ikan untuk budidaya ikan cupang, keterbatasan pakan hidup di lokasi mitra akibat banyaknya pembudidaya dan menurunya kualitas lingkungan, kurangnya keterampilan mitra menggunakan teknik "apartement" bagi budidaya cacing sutra. Berdasarkan permasalahan tersebut Tim PKM Universitas Samudra melakukan pengabdian dengan judul "Pelatihan Penerapan Sistem 'Apartement' bagi Budidaya Cacing Sutra pada Kelompok Pembudidaya Ikan Cupang di Desa Kampung Baru Kecamatan Langsa Lama, Langsa" sebagai solusi pemecahan masalah dalam pencapaian produksi ikan cupang secara kontinu dan berkelanjutan. Pengabdian ini sesuai hasil diskusi dengan mitra Kelompok Pembudidaya Ikan untuk meningkatkan hasil produksi ikan cupang. Berdasarkan analisis situasi dan permasalahan yang dihadapi oleh kelompok Pembudidaya Ikan Kampung Baru, maka tim pelaksana Pengabdian Kepada Masyarakat menawarkan solusi untuk memecahkan permasalahan yang dihadapi, seperti yang ditabulasi dalam Tabel 1 berikut ini. 
Tabel 1. Permasalahan, Solusi dan Target Luaran dari Solusi yang Ditawarkan

\begin{tabular}{llll}
\hline No & \multicolumn{1}{c}{ Permasalahan } & Solusi Pemecahan Masalah & \multicolumn{2}{c}{ Target Luaran } \\
\hline 1. & $\begin{array}{l}\text { Biaya pakan pelet ikan } \\
\text { untuk budidaya ikan cupang } \\
\text { yang tinggi }\end{array}$ & $\begin{array}{l}\text { Sosialisasi budidaya cacing } \\
\text { sutra sebagai pakan hidup }\end{array}$ & $\begin{array}{l}\text { Meningkatkan pengetahuan } \\
\text { tentang pembuatan budidaya } \\
\text { cacing sutra sebagai pakan } \\
\text { hidup ikan }\end{array}$ \\
\hline 2. & $\begin{array}{l}\text { Kurangnya keterampilan } \\
\text { budidaya cacing sutra } \\
\text { sebagai pakan hidup untuk } \\
\text { ikan cupang }\end{array}$ & $\begin{array}{l}\text { Pelatihan budidaya cacing } \\
\text { sutra sebagai pakan hidup } \\
\text { untuk ikan cupang }\end{array}$ & $\begin{array}{l}\text { Meningkatkan keterampilan } \\
\text { mitra dalam penyediaan } \\
\text { cacing sutra sebagai pakan } \\
\text { hidup }\end{array}$ \\
\hline 3. & $\begin{array}{l}\text { Keterbatasan pakan hidup } \\
\text { di lokasi mitra }\end{array}$ & $\begin{array}{l}\text { Pembuatan wadah/bak } \\
\text { apartement untuk budidaya } \\
\text { dan stok pakan hidup berupa } \\
\text { cacing sutra }\end{array}$ & $\begin{array}{l}\text { Penambahan aset berupa } \\
\text { wadah/bak apartement cacing } \\
\text { sutra serta peningkatan jumlah } \\
\text { omset mitra }\end{array}$ \\
\hline
\end{tabular}

\section{METODE}

Metode yang digunakan dalam kegiatan PKM dimulai dari tahap wawancara untuk merumuskan dan menentukan permasalahan yang menjadi prioritas, sosialisasi terkait program PKM, pendampingan kegiatan yang dilakukan sejak pelatihan hingga tercapainya tujuan pengabdian, monitoring dan evaluasi untuk menilai keberhasilan dan keberlanjutan program. Tahapan pelaksanaan program tertera pada Gambar 1:

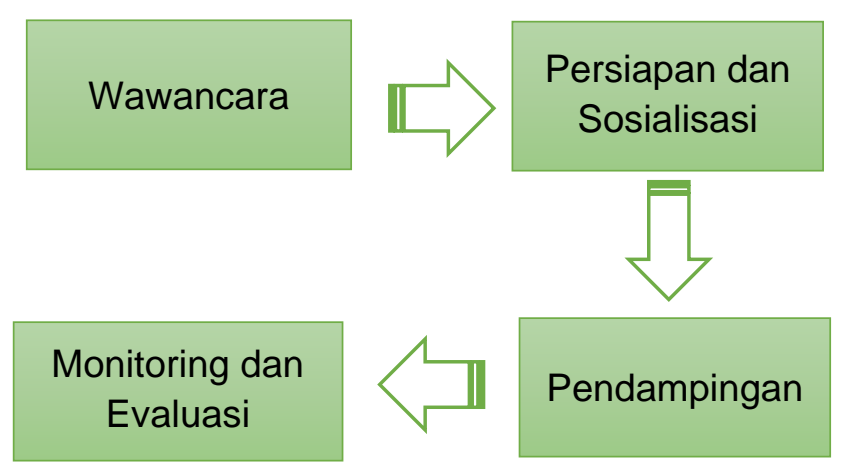

Gambar 1. Tahapan Kegiatan Pelaksanaan PKM

Tahap wawancara dilakukan dengan mitra untuk mengetahui permasalahan yang terjadi selama ini dalam budidaya ikan cupang serta menawarkan solusi untuk menjawab permasalahan yang dihadapi oleh mitra. Persiapan meliputi penyediaan alat dan bahan yang dibutuhkan dalam kegiatan PKM. Sosialisasi dilakukan untuk memberikan informasi yang lebih jelas kepada Kelompok Pembudidaya ikan cupang tentang maksud dan tujuan tim pelaksana untuk mengadakan pelatihan penerapan sistem 'Apartement' bagi Budidaya Cacing Sutra pada Kelompok Pembudidaya Ikan Cupang di Desa Kampung Baru Kecamatan Langsa Lama, Langsa.

Kegiatan pendampingan dilakukan oleh tim pelaksanaan pengabdian dengan mengunjungi lokasi pelatihan di Kampung
Baru, Kecamatan Langsa Lama selama dua kali sebulan. Hal ini bertujuan untuk memonitoring dan mengevaluasi perkembangan hasil kegiatan. Pada saat kunjungan, tim pelaksanaan akan berdiskusi dengan mitra mengenai perkembangan kegiatan, pengolahan dan permasalahan yang dihadapi pada saat melakukan pembudidayaan pakan hidup serta tim pelaksanaan juga akan memberikan motivasi dan tambahan informasi terkait pengembangan kegiatan. Monitoring dan evaluasi dilakukan untuk mengetahui ketermanfaatan program PKM pada mitra dan umpan balik yang diberikan.

\section{HASIL DAN PEMBAHASAN}

Pendampingan yang dilakukan pada PKM berupa pelatihan pembuatan Apartement cacing sutra dan pembuatan pakan cacing sutra dari ampas tahu yang di fermentasikan. Pembuatan Apartement bagi cacing sutra disini dengan menggunakan sistem resirkulasi dimana air mengalir secara terus menerus. Budidaya cacing sutra sistem apartemen dapat memberikan efek resirkulasi yang baik untuk kinerja pertumbuhan cacing sutra. Pembuatan Apartement bagi cacing merujuk kepada Balai Besar Perikanan Budidaya Air Tawar (BBPBAT) Sukabumi (2018) yang menyetakan bahwa salah satu cara mempertahankan kehidupan cacing sutra secara budidaya yaitu dengan sistem resirkulasi.

Sistem apartemen ini didesain dengan menempatkan bak-bak budidaya tersusun secara vertikal dengan menggunakan rak kayu. Setiap rak bisa menampung empat wadah plastik secara vertikal (empat tingkat). Dimensi setiap wadahnya adalah 1,8 (panjang) x 0,8 (lebar) x 0,2 (tinggi) meter kubik $\left(\mathrm{m}^{3}\right)$ (Gambar 2). Ukuran wadah tersebut bisa disesuaikan dengan kebutuhan dan kondisi lahan. Tujuan utama sistem apartemen ini yaitu untuk memperluas area budidaya cacing sutra pada 
lahan terbatas. Selain menghemat lahan budidaya, sistem apartemen ini juga memiliki keunggulan melalui pengurangan penetrasi langsung cahaya matahari ke dalam wadah budidaya. Cahaya matahari yang berlebih pada budidaya cacing bisa meningkatkan keberadaan lumut, teritip, dan keong yang bisa mengganggu proses produksi.

Selanjutnya pembuatan pakan cacing sutra dari ampas tahu yang difermentasikan dapat menjadi alternatif pakan sekaligus substrat yang tepat dalam mendukung kelulushidupan dan perbanyakan cacing sutra. Penggunaan ampas tahu sebagai pakan pada budidaya cacing sutra selain mudah diperoleh juga karena harga beli yang relative murah sehingga tidak memberatkan modal bagi para pembudidaya cacing sutra nantinya. Pembuatan pakan dimulai dengan memeras ampas tahu hingga kering lalu letakkan secara bertaburan diwadah. Selanjutnya menambahkan EM4 dan molase lalu diaduk hingga merata hingga membentuk warna kecoklatan dengan aroma yang tidak menyengat, pencampuran tersebut dilakukan agar bertambahnya unsur mineral dalam pakan untuk cacing sutra (Fadhlullah, 2017). Selanjutnya ampas tahu yang telah diberi perlakuan tersebut diamkan selama 3 hari pada wadah tertutup. Setelah 3 hari ampas tahu yang telah difermentasi siap digunakan bagi pakan cacing sutra. Pakan cacing sutra dari ampas tahu yang difermentasikan dapat dilihat pada Gambar 3.

Dalam kegiatan pengabdian ini, di mulai dengan menyampaikan materi terkait persiapan alat dan bahan, metode pembuatan sistem apartemen dan pembuatan pakan cacing, teknik sebar, dan lain-lain kepada kelompok pembudidaya yang hadir sekaligus berdiskusi secara langsung terkait pelatihan penerapan sistem Apartement bagi budidaya cacing sutra (Gambar 4). Diskusi dilakukan untuk bertukar informasi terkait pembuatan sistem budidaya, pemeliharaan, pemanenan dan pengemasan.

Selanjutnya pelatihan terkait pengawetan cacing sutra juga dilakukan secara langsung, hal ini dilakukan agar pembudidaya dapat memproduksi cacing sutra secara kontinu dengan kualitas cacing sutra segar dan awetan. Pelatihan metode penyimpanan ini dilakukan untuk memperoleh masa simpan yang lebih lama terhadap cacing sutra sehingga dapat mengatasi pemasalahan pakan budidaya ikan cupang, mulai dari penyediaan pakan, mengelola air hingga kelanjutan usaha.

Dalam mendukung usaha yang berkelanjutan serta menjadikan contoh bagi pengembangan sistem budidaya cacing sutra, maka tim pengabdian menyerahkan alat alat dan media yang sudah menjadi sistem Apartement bagi pembudidaya cacing sutra kepada kelompok budidaya ikan cupang yang diakhiri dengan foto bersama kelompok pembudidaya, tim pengabdian, para mahasiswa, dan masyarakat sebagai wujud keseriusan dalam keberlanjutan usaha pada kelompok budidaya ikan hias (Gambar 5 dan Gambar 6).

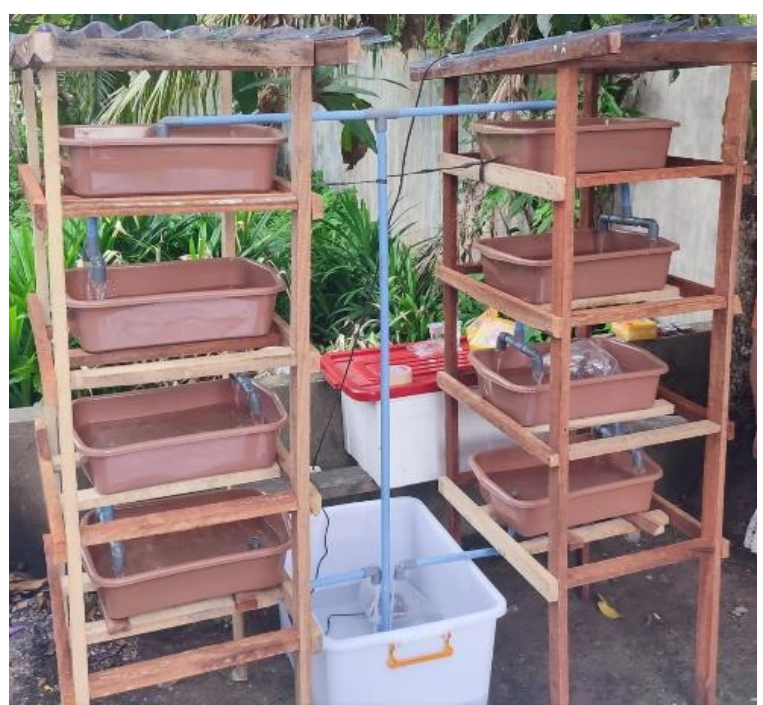

Gambar 2. Sistem Apartement Cacing Sutra 


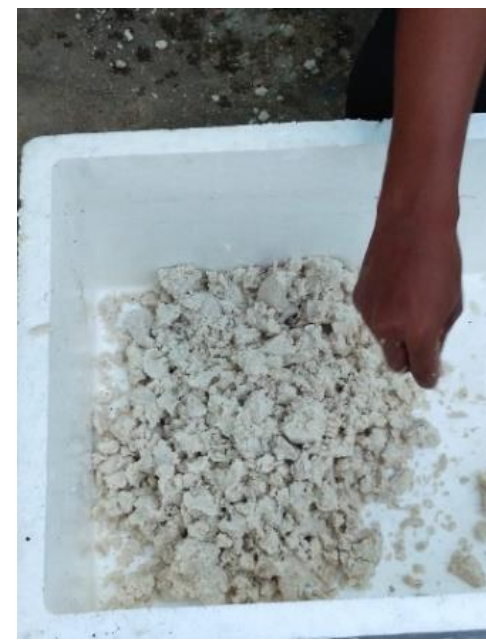

(a)

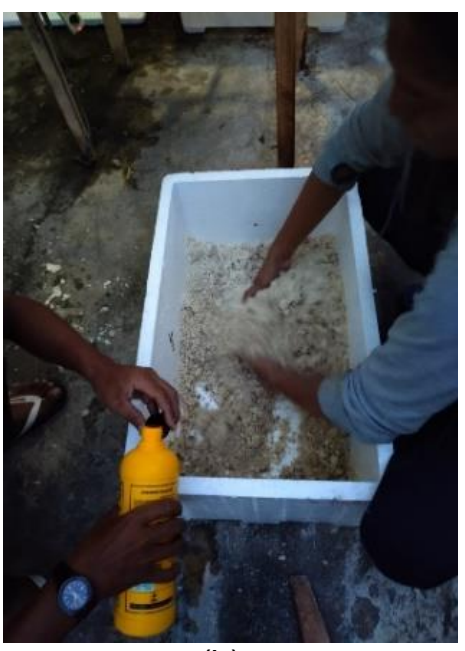

(b)

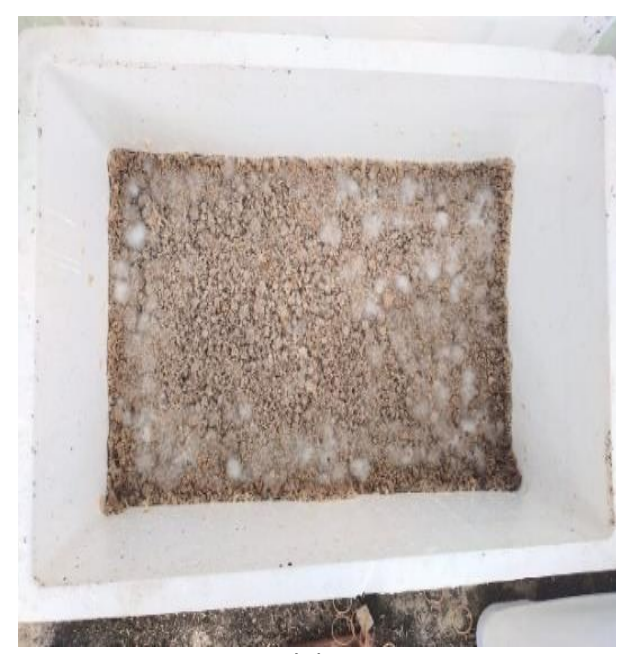

(c)

Gambar 3. Ampas tahu (a) Pencampuran pakan (b) dan Pakan fermentasi

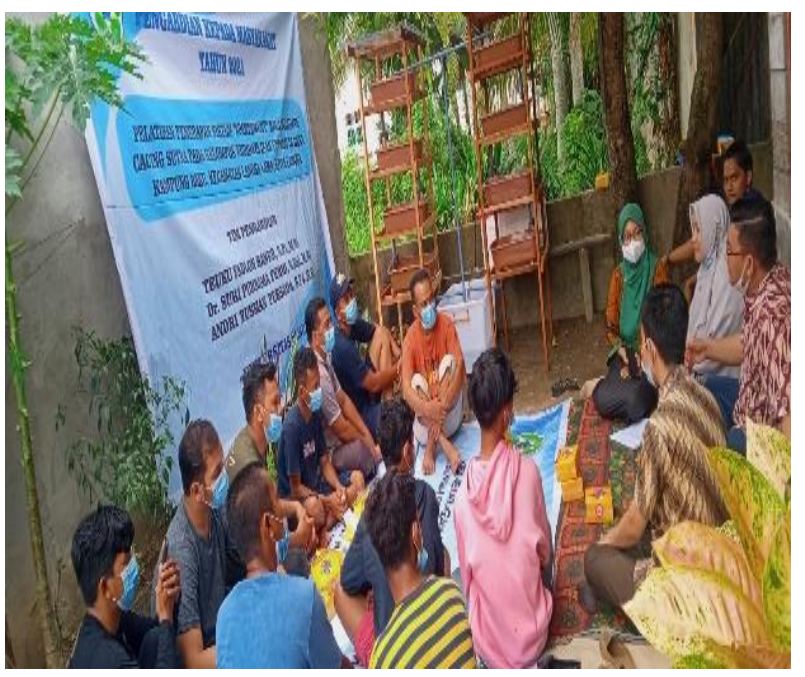

Gambar 4. Penyampaikan materi oleh Tim PKM

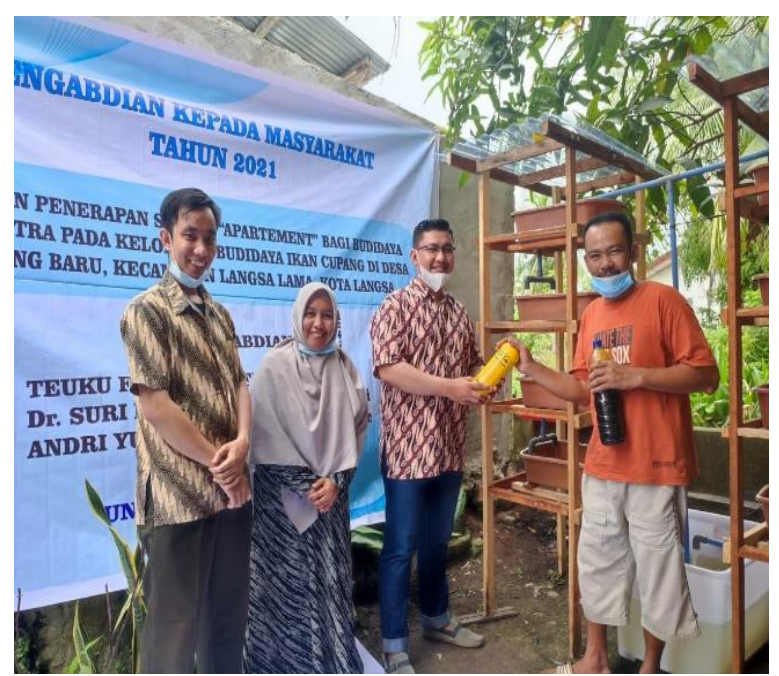

Gambar 5. Serah Terima Sistem Apartement

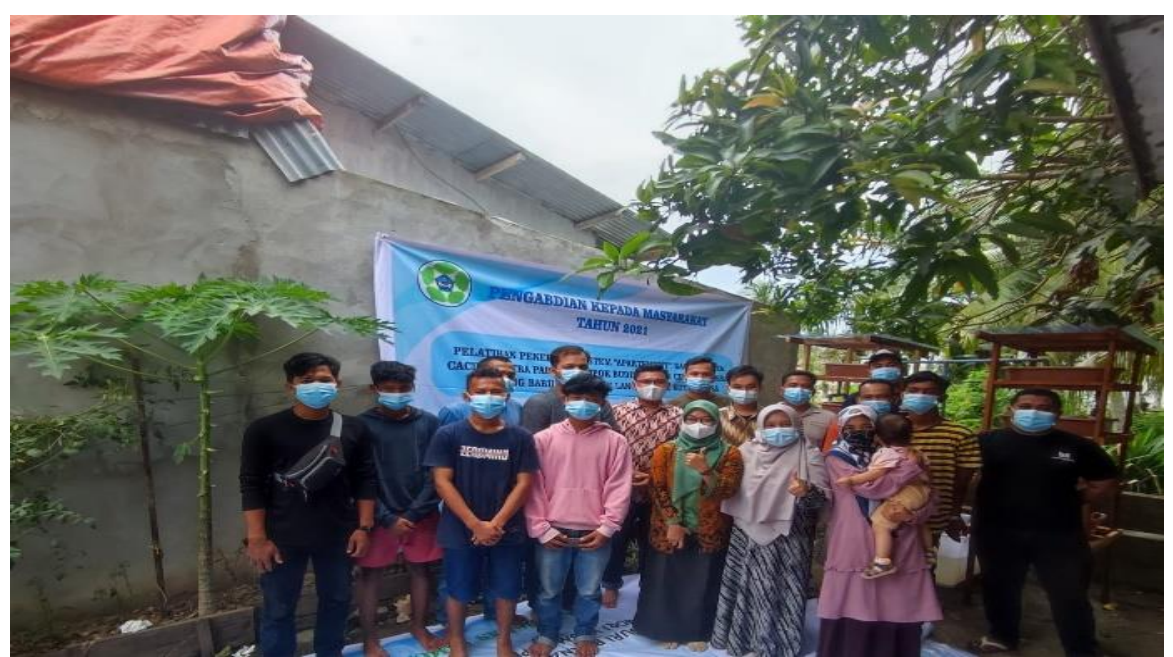

Gambar 6. Dokumentasi bersama Kelompok Budidaya ikan cupang, masyarakat dan Mahasiswa 


\section{SIMPULAN DAN SARAN}

Kesimpulan yang dihasilkan dari kegiatan pengabdian kepada masyarakat di Desa Kampung Baru, Kecamatan Langsa Lama, Kota Langsa yaitu dapat meningkatkan pengetahuan dan keterampilan mitra dalam pembuatan serta penyediaan cacing sutra sebagai pakan hidup bagi ikan cupang dengan penerapan sistem Apartement. Selanjutnya menciptakan usaha baru bagi mitra yakni budidaya cacing sutra sehingga dapat meningkatkan perekonomian keluarga selain dari budidaya ikan cupang.

\section{UCAPAN TERIMAKASIH}

Penulis mengucapkan terima kasih kepada Universitas Samudra yang telah mendanai kegiatan PKM tahun 2021 melalui Hibah Pengabdian Kepada Masyarakat. Penulis juga mengucapkan terima kasih kepada Rektor Universitas Samudra, Pemerintah Kecamatan Langsa Lama Kota Langsa, Geuchik Desa Kampung Baru serta seluruh anggota kelompok Pembudidaya Ikan Cupang di Desa Kampung Baru yang telah berpartisipasi dalam kegiatan yang dilakukan.

\section{DAFTAR RUJUKAN}

[BBPBAT] Balai Besar Perikanan Budidaya Air Tawar Sukabumi. (2018). Apartemen Cacing Tingkatkan Produktivitas. https://kkp.go.id/artikel/29410-

apartemen-bagi-cacing-sutra-solusi-

pakan-ikan-alternatif (Diakses pada Tanggal 10 Agustus 2021).

Diani, S., Mustahal dan Sunyoto, P. (2005). Usaha Pembenihan Ikan Cupang (Betta sp) di Kabupaten Serang. Jurnal Pengkajian dan Pengembangan Teknologi Pertanian, Vol. 8 (2): 292299.

Effendi, M. (2017). Beternek Cacing Sutera Cara Modern. Jakarta: Penebar Sawaday.

Fadhlullah, Muhammadar, El Rahimi SA. (2017). Pengaruh Perbedaan Konsentrasi Pupuk Organik Cair Terhadap Biomassa dan Populasi Cacing Sutera (Tubifex Sp.). Jurnal IImiah Mahasiswa Kelautan dan Perikanan Unsyiah. 2 (1): 41-49.

Febrianti S, Dadang, S dan Eddy, S. (2020). Budidaya Cacing Sutra (Tubifex sp.) dan Budidaya Ikan Lele Menggunakan Sistem Bioflok di Kecamatan Simpenan, Sukabumi. Jurnal Pusat Inovasi Masyaraka.Vol. 2 (3): 429-434

Hamron, N., Johan, Y dan Brata, B. (2018). "Analisis Pertumbuhan Populasi Cacing Sutera (Tubifex sp) Sebagai Sumber
Pakan Alami Ikan. Jurnal Naturalis, Vol. 7 (2): 79-89.

Prasadi, O. (2019). Pemanfaatan Lahan Sempit sebagai Tempat Budidaya Ikan Cupang di Mertasinga, Cilacap. E-DIMAS Jurnal Pengabdian Kepada Masyarakat, Vol. 10 (1): 83-88. 